\title{
SOCIO-ECONOMIC STATUS OF BEGGARS IN URBAN AREAS AND THEIR INVOLVEMENT IN CRIMES: A CASE STUDY OF KARACHI CITY
}

\author{
Sakina Riaz
}

Muhammad Abrar ${ }^{* *}$

\begin{abstract}
The present research paper aims to find out the life patterns of urban beggars' demographic characteristics, socio-economic status and their involvement in criminal activities in Karachi city. A descriptive research design was employed and face to face interviews were conducted in this study. A sample of 140 street beggars, were selected from different public places using a convenience sampling technique. Both quantitative and qualitative methods were utilized for data collection. The key findings of the study show that criminal beggars are organized and have the well-kept house and work in routine as front-line professionals in the city. This study recommends that a comprehensive policy should be implemented to control the begging practice in the city. In this regards a proper advocacy campaign is needed for social mobilization at mass the level.
\end{abstract}

Keywords: Socio-Economic Status, beggars, begging behaviour, urban problem, Karachi

\section{Introduction}

Begging is perceived as an international social problem. Evidently, it is sarcastic, since Begging is noticeable as an urban known social phenomenon of the twenty-first century. Beggars found everywhere like on the streets, at all traffic signals, around the mosques or shrine, churches, and temples, at shopping places and all other public gathering or entertainment places, Beggars are omnipotent and unstoppable.

Traditionally, a beggar is an individual who requests for assistance or charity who are not able to earn money or unable to survive. Currently, it has become a profession, many people are eagerly begging even they are capable to earn money.

Certainly, begging is a heterogeneous phenomenon and has trailed in almost every society, although its dominance is different from culture to culture. It is very difficult to define that why people choose this activity? Begging has different reasons and ground for its continuing practice in diversified culture. It is not due to the maneuver of a single reason. It is the consequence of a variety of socio- economical and biological aspects. Still, it is the product of perpetuating poverty, social inequality, and unsustainable economy.

\footnotetext{
* Sakina Riaz, Ph.D. Assistant Professor, Department of Social Work, University of Karachi

${ }^{* *}$ Muhammad Abrar, Assistant Professor, Department of Social Work, University of Peshawar
} 
Beggars use a number of strategies to take money from others as their "earning". There are varieties of places where beggars are found working. They are very vigilant in doing their job. They use different tactics for different individuals in order to get their sympathy. On this ground, it can be assumed that several actually adequate young men are frequently seen pleading on the streets because they think they can earn more money through begging rather than through laboring all day.

Indeed, beggars are dynamic and the visible, part and parcel component of life in urban hamlets, where the population rises rapidly. Yet, in urban areas, there are greater chances for many Beggars to sustain this job in a different location of the city.

The concept of 'Beggars' involvement in crime in urban areas' is a serious social issue which encompasses a wide range of concerns for safety and financial security of the common urban residents. These range from robbery, kidnapping, ransom, violence and many other street crimes compounded by their fast progression typically in urban areas.

The tradition of begging has long roots indifferent culture and also closely associated with religion. In Pakistani society begging is treated within the purview of the religion. Thus, a beggar is a person who recognized as poor and needs support of others in fulfilling the basics human need. In various religions like in Islam, Christianity and even in Hinduism seeking alms is an opportunity to earn God's blessings. ${ }^{1}$ This situation becomes more critical if any beggar has been suffering from any chronic disease like leprosy and mental illness, it tacitly criminalizes the illnesses. ${ }^{2}$

Due to the scarcity of the record, it is uncertain to trace when begging started in Pakistan and when it originated in urban areas of the Country. How beggars involved in anti social activities? Certainly, there are a number of social-cultural and political factors are involved to influence beggar's involvement in criminal activities such as support of militant wings of political parties, weak governance system, illiteracy, and poverty are the key-contributing factors among beggars' involvement in criminal activities. This research is an effort to disclose the link between the beggars and their involvement in anti-social activities in Karachi and find out the way to control these phenomena

\section{Literature Review}

Begging has been initiated as social practice since the existence of human society. It is viewed as one of the oldest challenges for human society. Historically, Begging had noted in Greece amongst the initial period and the Byzantine era. ${ }^{3,4}$

Several research reviews have been published on begging behavior. For instance, Tripathi and Arora $^{5}$ had viewed begging as soliciting or receiving alms in public place by

\footnotetext{
${ }^{1}$ Kaushik,A. Rights of Children: A Case Study of Child Beggars at Public Places in India" Journal of Social Welfare and Human Rights, (2014),Vol. 2, No. 1, pp.1-16

${ }^{2}$ Mander, Harsh The war against begging, The Hindu. (2009, January 25)

${ }^{3}$ Johnny, J. "In tough times, panhandling may increase in Oklahoma City". (The Oklahoma, 2008).

${ }^{4}$ Alan, E. "Use of recreation as an adjunctive therapy in medical treatment and rehabilitate of beggars". A paper presented at the annual conference of CASSON, Kano, 2012, pp.4-12
} 
exposing wound, injury, deformity or disease whether of himself or of any other person or animal. Nevertheless, Begging is very critical and complex in nature. It is observed that voluminous tactics have been used by beggars for begging. For example, a sick young street beggar generally attracts the sympathy of the common man. ${ }^{6}$ Tanvir $^{7}$ noticed that many beggars used different strategies to attract people. For example, women with very young babies in their laps cause people to give them alms. Broun ${ }^{8}$ considered begging as a charge on the failure or weak governance in several cultures, ${ }^{9}$ observed begging as the practice of pleading others to provide financial support like money, clothes or food with no anticipation of exchange or refund. Boaten ${ }^{10}$ Yilmaz and Dülgerler ${ }^{11}$ noted that "street children and begging as an ordinary phenomenon".

Some scholars considered begging for an occupation. ${ }^{12,13}$ Chukwulobe $^{14}$ viewed that "street begging is seen as an act of stopping people on the street to beg for assistance". It frequently happens for obtaining a monetary assistance, usually in cash or charitable contribution. ${ }^{15}$ Balogun ${ }^{16}$ pointed out that a street beggar is a person who depends on others without doing any services in return.

Moreover, it is noticed that in many cases individual with disabilities, or physical disability; is generally observed that family members may encourage them to beg. ${ }^{17}$ Beggars with disability are also seen in some countries living in groups with united social

5 Tripathi, S. C. and Arora, Vibha. Law Relating to Women and Children, (Allahabad: Central Law Publications, 2010), p.354.

${ }^{6}$ Fives, A; Kennan, D; Canavan, J; Brady, B and Cairns, D. Study of Young Carers in the Irish Population. (Dublin: Government Publications, 2010).

${ }^{7}$ Tanvir. "Beggars declassified" available at: http://stolenemotions.wordpress.com/2011/05/18/beggarsdeclassified/ (2011) (accessed on 20-4-15)

${ }^{8}$ Broun, Idiege, B., Ube, M. and Bisong, M.D counseling youth Against drugs abuse: Implication for human development. Conference proceeding. 34th Annual SCASSON conference. (2010), pp.20-28

${ }^{9}$ Usoro, H. et al. The prevalence of street begging in Cross River State: Implication for Counselling and Vocational Counselling. (Paper presentation at the CASSON Conference 2007), pp.5-12

${ }^{10}$ Boaten, A.B. "An Examination on the Phenomenon of Street Children in Selected Communities in Accra (Ghana", A Dissertation Presented to the Faculty of the College of Education of Ohio University in Partial Fulfillment of the Requirements for the Degree Doctor of Philosophy. (Ohio: Ohio University Press, 2006)

${ }^{11}$ Yilmaz, H. B and Dülgerler, S. Children who work in the Street in Izmir, Turkey. (Izmir: Ege University, Izmir, 2011), pp.129-144

${ }^{12}$ Ogunkan, D.V. and O.A. Fawole. "Incidence and socio-economic dimensions of begging in Nigerian cities: The case of Ogbomoso". International NGO Journal., 4(12): (2009), pp.498-503. Available on: http://www.academicjournals.org/journal/INGOJ

${ }^{13}$ Adedibu, A.A. \& Jelili, M.O. Package for controlling street begging and rehabilitating beggars and the physically challenged in Nigeria: Paper for policy consideration. Global categories of street beggars and factors influencing street begging. Journal of Human Social Science, (USA: Global Journals Inc. 2011),11(1):, pp.1724. Available on :

https://globaljournals.org/GJHSS_Volume11/2_Package_for_Controlling_Street_Begging_and_Rehabilitating.p df

${ }^{14}$ Chukwulobe, C. "Street Begging and its prevalence in Niger State". (Unpublished project, 2011), pp.2-15

${ }^{15} \mathrm{John}, \mathrm{O}$. Street begging a menace. Available on: https://www.scribd.com/document/46783864/Romanism-AMenace-to-the-Nation . (2010) (assessed on 21 June 2015)

${ }^{16}$ Balogun, A. New forms of begging on Lagos Street. The Punch Newspaper, (17 $7^{\text {th }}$ March 2012)

${ }^{17}$ Groce, Nora; Loeb, Marie; Murray, Barbara. "The Disabled Beggar - A Literature Review, Begging as an overlooked issue of disability and poverty". International Labour Office; Gender, Equality and Diversity Branch, Geneva 22, (Switzerland: 2014), pp.1-26 
support mechanisms and security for their groups. For instance, "Beggar Brotherhoods" in India. ${ }^{18}$

However many kind of researches supported that begging has a strong association with poverty and anti-social activities. There are many begging groups who coerced common people into begging or some people are forced to beg ${ }^{19}$ and keep the profit or take their share. It is viewed that these groups are generally supervised by "businessmen" or criminal gangs or mafias. Most of them are living in a very bad situation, the risk of maltreatment, forcefulness or even the assassination too. ${ }^{20,21}$

Tambawal, ${ }^{22}$ Namwata et al., ${ }^{23}$ Adedibu $^{24}$ have mentioned that there is a strong link between deviant behaviors and street begging. Evidently, it is important to notice that the efforts on criminalizing and forbidding or arresting beggars have not evidenced mostly operative. ${ }^{25,26,27}$

In a study conducted by the government of Morocco, it was observed that 62.4 percent of beggars had bank accounts. ${ }^{28}$

In a research, published by ILO in 2004, it is well-versed that "some middle-class people have added to their income through begging after working hours in Pakistan" ${ }^{29}$ Abdallah

${ }^{18}$ Kumarappa, J.M. Our Beggar Problem and How to Tackle It, (Bombay, India: Peffer Press, 2007), pp.1-324

${ }^{19}$ Sabina. "The Condition of Bangladesh Beggers", available at http://gurumia.com/2010/04/12/the-conditionof-bangladesh-beggers/ (2010), (assessed on 21 June 2015)

20 Saini, V. "Beggary: Issue and Challenge for the City Beautiful, Chandigarh". available at: http://www.articlealley.com/article_857569_63.html (2009), (assessed on 24 June 2015)

${ }^{21}$ Malone, A. "The Real Slumdog Millionaires: behind the cinema fantasy, mafia gangs are deliberately crippling children for profit". Daily Mail. 24 Jan. (2009), Available at:

http://www.dailymail.co.uk/news/worldnews/article-1127056/The-real-Slumdog-Millionaires-Behind-cinemafantasy-mafiagangs-deliberately-crippling-children-profit.html (accessed on 21 June 2015)

${ }^{22}$ Tambawal, M.U. The Effects of Street Begging on the National Development: Counselling Implications. A Paper Presented at the 1st national Conference of the Counselling Association of Nigeria (CASSON) Katsina State Chapter from 7th-10th June 2010. Faculty of Education and Extension Services, Department of Educational Foundations, (Sokoto: Usmanu Danfodiyo University, 2010)

${ }^{23}$ Namwata, B.M.L., Mgabo, M.R. \& Dimoso, P. Categories of street beggars and factors influencing street begging in central Tanzania. African Study Monographs, (2012, June), 33(2): 133-143.

${ }^{24}$ Adedibu, A.A. \&Jelili, M.O. Package for controlling street begging and rehabilitating beggars and the physically challenged in Nigeria: Paper for policy consideration. Global categories of street beggars and factors influencing street begging. Journal of Human Social Science, (2011), 11(1): 17-24.

${ }^{25}$ Lynch, P. "Understanding and responding to begging". Melbourne University Law Review. Available at: http://www.austlii.edu.au/au/journals/MULR/2005/16.html (2005) (accessed on 21 July 2015)

${ }^{26}$ Rahman, M. "Bangladesh plans jail threat to deter beggars". The

Guardian.http://www.guardian.co.uk/world/2009/apr/03/bangladesh-jailbeggars. (2009), [Accessed 19 June 2015].

${ }^{27}$ Johnsen, S.; Fitzpatrick, S. "The use of enforcement to combat begging and street drinking in England: a high risk strategy?" European Journal of Homelessness, (2008), Vol 2, pp.191-204

${ }^{28}$ Lahcen, M. "Morocco expands campaign against begging".

Magharebia.http://www.magharebia.com/cocoon/awi/xhtml1/en_GB/features/awi/features/2008/09/29/feature01. (2008), (accessed on 21 June 2015)

${ }^{29}$ International Labour Organization "A rapid assessment of bonded labour in domestic work and begging in Pakistan". (Karachi, Collective for Social Science Research, 2004), Working Paper No. 22. 
Jacob Seni ${ }^{30}$ suggested that training is required for "influential community members" in controlling begging practices.

The researcher used two theories of vicious circle of poverty and functionalist for theoretical framework of the present study. The theory of "vicious circle of poverty" pursues to clarify the perseverance of poverty in the society and specifies that poverty as a subculture transfer from one generation to the next and becomes institutionalized amongst the poor Baltazar M.L. Namwata et al. ${ }^{31}$ It is one of the key element which formulates the pulverized for the phenomenon of begging. This theory also highlights on people's inability to cope risk as a way of breaking the vicious circle of poverty. Additionally, Ogunkan and Fawole ${ }^{32}$ have noticed the characteristics of poverty are deprived health, deficiency of talents, shortage of self-confidence, inaccessibility from the marketplace, shortage of physical asset, malnourishment or combination of the above. Under this situation, the poor are surrounded in the position with a minute chance of escaping such that in a vicious process and in this way poverty is sustained among the poor through the generations. Thus, for the poor in fulfilling their elementary needs, begging is an alternative option for them. The vicious circle of poverty supports to explain the actuality of begging through the generations. ${ }^{33}$

The structural functionalism is a wide perspective in sociology which views society as a structure with interrelated parts in terms of the function of its integral elements such as family, religion, economy, education and government. Constructed on this theory, it is vibrant that street begging is a result of the weak functioning or failure of social institutions and may leads to promote begging and beggars' involvement in anti-social activities.

\section{Objectives of the Study}

This study was undertaken to identify the socio-economic status of street beggars and their involvement in anti-social activities with reference to Karachi city. Reflecting the insufficiency of research regarding begging practices in Pakistan, the researcher prepares following study objectives:

- To determine the socio-economic characteristics of the beggar population in Urban areas of Karachi;

- To ascertain trends, practices and life patterns of Urban Beggars in Karachi;

\footnotetext{
${ }^{30}$ Abdallah Jacob Seni. "The Experiences and Perceptions Encountered by Young Carers of Visually Impaired Adult Beggars in Tanzania: Implications for access to basic education". European Journal of Education Studies. (2016), Vol.2, Issue 1, pp:91-109

${ }^{31}$ Baltazar M.L. Namwata Maseke R. Mgabo , Provident Dimoso, Feelings Of Beggars On Begging Life And Their Survival Livelihoods In Urban Areas Of Central Tanzania, International Journal Of Physical And Social Sciences, (2012), Vol.2(7) pp:306-322

${ }^{32}$ O. A. Fawole, D. V. Ogunkan, and A. Omoruan. The Menace of Begging in Nigerian cities: A Sociological Analysis. International Journal of Sociology and Anthropology, (2010), Vol. 3(1), pp.9-14

33 Jelili M.O. "Environmental and Socio- economic Dimensions of Begging in Ilorin and Ogbomoso.Unpublished M.Tech dissertation, Department of Urban Regional Planning, (Nigeria: Ladoke Akintola University of Technology, Ogbomoso, 2006) p.4
} 
- To find out the causes of begging and their involvement in crimes in Urban areas of Karachi.

\section{Significance of the Study}

The study has manifolds importance as it provides information about the beggars' lifestyle and helps to understand their socio-economic status and their involvement in anti-social or criminal activities. It will also help to understand the phenomena of begging and explain the Beggar's perspective regarding begging practices in Karachi city.

\section{Methodology}

Due to non-availability of accurate statistics about beggars, it was very difficult for the researcher to find out the actual number of beggars living or working on the street in Karachi. Therefore, the allocation of the sample was a tough task. It was observed during the field visits that the beggars have frequently changed their places and reallocated at numerous localities in the city. Hence, many attempts were made to evaluate the exact number of individuals involved in begging and criminal activities. This was really a challenging job for the researcher as beggars were spread over a huge area and their number varied on a daily basis and during different hours. Therefore the only conceivable source to obtain numbers was the observation. Lastly, as a matter of fact, the researcher born and lived in this city for most of her life made her familiar to understand with begging activities and used personal contacts of many people in approaching the respondents.

A research descriptive design was employed to elicit the required information and the researcher used both quantitative and qualitative methods for data collection in this study.For quantitative analysis, a sample of one hundred and forty $(n=140)$ street beggars was obtained from numerous public places in the urban areas of Karachi, with the help of informal contacts, accompanied by taking informed consent from the participants. The researcher used convenience sampling technique. A specially designed questionnaire was used as a data collection tool in the present study. The sample was collected through face to face interviewed method for data collection, after taking informed consent from respondents. Only those beggars were included who have been engaged in begging since last two years in the city.

Besides this, for qualitative analysis, direct observation, field notes were also made which consisted: who does what (the nature of interactions); whether beggars involved in begging directly, or indirectly? Do they involved in different activities in assisting to the beggary such as selling small items; when (the times in which begging did or did not take place); where (spatial distribution in key locations); and for how long (duration of interactions). Moreover, physical characteristics like their gender, age and behavior characteristics, such as body movement and facial expressions, gestures, postures, dressing style, were also observed by the researcher during the course of data collection.

Apart from the above, the researcher had collected two face to face interviews with Social workers and one from a street Beggar, to understand this phenomenon in detail. 
This study was limited to the inner-city area of the city. Chi-square was calculated to see the relationship between different variables.

\section{Discussion \& Results}

Socio-economic status of beggars in urban areas and their involvement in crimes is one of the most fundamental aspects of Karachiaits's life and considered to be a sensitive issue for discussion because of politico- religious and socio-economic sensitiveness of the city. A number of factors are responsible for creating and supporting this situation. For example, all forms of neglect, abuse, trauma, poverty and inadequate parenting, weak law and order situation could have a negative effect on an individual's development, both psychological and economical level and may lead to involve them in anti-social activities like begging. In order to help the individual, groups or communities as a social worker, this research was conducted to focus the urban lifestyle in Karachi, whose needs are paramount.

The results and discussions of the findings of this study are presented by using both quantitative and qualitative methods of analysis:

- For quantitative analysis, a sample of one hundred and forty $(n=140)$ street beggars were approached by using convenience sampling technique.

- For qualitative analysis, an in- depth interview with Key informants were conducted separately with a social welfare officer working in Sindh Government, a social worker working in NGO and a street beggar by using face to face interview and observation techniques.

About one hundred and forty street beggars (140) were interviewed; using selfadministered questionnaires to collect each respondent's data. Results showed the gender of the study sample, $41.2 \%$ were female, $38.8 \%$ were male and $20 \%$ respondents declare that they belong to a transgender group.

As far as the residing conditions, interestingly, this research showed that $(30.2 \%)$ beggars have their own property, mainly in slum areas or extent of informal settlements and other slums. A majority of the respondents said that they were living as a tenant in a rented house (54\%) while others are living in their own homes and almost $16.7 \%$ stay with relatives respectively.

The data revealed that $48 \%$ beggars have electricity via Kunda system (illegal sources for getting Electricity) and have TV and fridge in their houses. 
Table:1

Frequency and percentage Distribution of Respondents

\begin{tabular}{|c|c|c|}
\hline Variables & Frequency & $\%$ \\
\hline \multicolumn{3}{|l|}{ Age } \\
\hline 18_28 years & 43 & 30.71 \\
\hline 28-38years & 24 & 17.1 \\
\hline $38-48$ years & 37 & 26.4 \\
\hline $48-58$ years & 28 & 20 \\
\hline 58 and above & 8 & 5.7 \\
\hline Total & 140 & 100 \\
\hline \multicolumn{3}{|l|}{ Level of education } \\
\hline Illiterate & 73 & 52.1 \\
\hline Primary level -Middle level & 27 & 19.2 \\
\hline Matriculation & 20 & 14.2 \\
\hline Intermediate & 12 & 8.5 \\
\hline Graduate and above & 8 & 5.7 \\
\hline Total & 140 & 100 \\
\hline \multicolumn{3}{|l|}{ Marital status } \\
\hline Unmarried & 19 & 13.5 \\
\hline Married & 108 & 77 \\
\hline Widow/divorced & 13 & 9.2 \\
\hline Total & 140 & 100 \\
\hline \multicolumn{3}{|l|}{ Family size } \\
\hline Below 5 members & 36 & 25.7 \\
\hline 6-8 members & 57 & 40.7 \\
\hline 9-11 members & 29 & 20.7 \\
\hline $12 \&$ more members & 18 & 12.8 \\
\hline Total & 140 & 100 \\
\hline
\end{tabular}

The above-mentioned data indicated that the majority of the respondent belonged to the age group of $18-28$ years, a majority were illiterate and about $77 \%$ married, a majority has a family size being about 6-8 members. The study data indicate that the majority of the respondents were Muslims, (64\%) and Hindu (30\%). Out of the total sampled, 56.2 \% are migrants while $43.8 \%$ beggars belong to Karachi. 
Data reveals that $71.3 \%$ were involved in begging activity and treat it as the full-time job. Interestingly, it was declared by the $28.6 \%$ respondent, that they are working as seasonal or part-time begging job and the rest of the time they were involved in additional activities of earning and normally self-employed.

The analysis stated that the economic status of beggars is better and the majority of them (45\%) earned rupees 500-650 in a day. The data indicated that $13.0 \%$ beggars are the smoker, $26 \%$ are Gutka and tobacco users, $17 \%$ drinkers and remaining $44 \%$ are spoiled with added bad habits like chomping pan-masala, using drugs, and drink low quality and inexpensive alcohol. The data articulates that almost $85 \%$ beggars were physically and mentally healthy because of the way they answered and the way they talked clearly indicated it.

This study discloses that in Karachi Shopping Malls, Religious Places, Hospitals, Petrol pump stations and posh areas traffic signals have great attraction for begging. The study shows that shopping malls Clifton, Tariq Road, Nazimabad Round-about, Hyderi Bazar and sadder has been considered as the highest earning places for beggars and the areas of Nazimabad and Tariq Road are inseparable entities for the study of the problem.

In response to the questions about the hobbies and leisure activities, $22 \%$ replied that they arrange a picnic with family members once, in a year, 37\% expressed that they visited hotels with family and friends and treat it as a leisure activity. While $12 \%$ said they visited relatives' houses located in other cities or countryside for attending weddings or death ceremonies and considered it as an outing. Only $18 \%$ said that they visited Shrines of Sufis located at Clifton, Lasbella, Mewasha, Norani Darbar and listen to Qawwalis (Muslim Sufi Music) for getting internal satisfaction once in a month.

In response to a question about the social life pattern, surprisingly, it is revealed that $46 \%$ of the study respondents were highly satisfied with their existing lifestyle.

A majority of respondents $(83 \%)$ declared that they have formed good social relations with other colleagues or fellow beggars. Interestingly, this research confirms the finding of another study conducted by Woodhead, ${ }^{34}$ that 'beggars have satisfied their emotional needs for companionship, closeness, and protection and are an important source of identity on the street.

Refer to the question pertaining to beggars' involvement in criminal activities, data showed that beggars were involved in illegal drug trafficking, due to assurances of superior life and through phone call of traffickers about $37 \%$ of the respondent told that they were involved in drug selling or distribution in the city. However, most of the respondents $(63 \%)$ have been reluctant to handle this question and treat as an odd question. Only eleven respondents $(8.3 \%)$ were confessed to doing crime on a more regular basis, including theft, robbery, robberies and selling drugs.

${ }^{34}$ Woodhead, Martin (1998). Children's Perspectives on their Working Lives: a participatory study in Bangladesh, Ethiopia, The Philippines, Guatemala, El Salvador and Nicaragua. Radda Barnen, Stockholm, Sweden .Retrivedfrom :http://oro.open.ac.uk/28493/ on 13-6-2015. 
In a study conducted by United Nations Human Settlements Programme ${ }^{35}$ in 2007, observed that street children and youth are both victims and perpetrators of crime in cities due to survival needs and exposure to cultures of violence, including deviant peer behavior.Although, the researcher was unable to find any clear evidence that becoming beggars lead to becoming a criminal in urban areas.

Refer to the question about commonest crimes which they were occasionally to be involved in, was shoplifting during poor law and order situation in the city as indicated by $36 \%$ of respondents. Among $28 \%$ of the respondents denied that they are not involved in any sort of a crime. Only $16 \%$ of the respondents were disclosed as habitual offenders, $13 \%$ were declaring that they were presented before the Court. While $7 \%$ of the respondents were not shared their opinion. The results confirm the study of Balachova, Bonner, \& $\mathrm{Levy}^{36}$ as stated that in Russia, children are involved in stealing/robbery, collecting empty bottles, car cleaning and carrying loads.

Many of the respondents (68\%) were reported that they are also victims of police torture. The data reveal the various significant consequences of begging as shared by the respondents were kidnapping (29.2\%) committed an offense and ran away from home $(23.8 \%)$ and street Crime (18.0\%), sexual exploitation (12.5\%), road accident (9.0\%), and Prostitution (16.3\%) respectively. The data showed that beggar was involved in prostitution from posh areas of the city like Clifton, Gulistan-e-Jauhar, Nazimabad and Bahadurabad as the respondents were disclosed that involved in prostitution and some were the victims of abuse.

Present research disclosed that out of the total selected beggars, $44.8 \%$ had chosen the begging as a source of earnings owed to great poverty. The second most important cause of begging was Alcoholism (30\%) of the respondents reported. Old age, diseases, disability and mental illness were another important cause of begging which shared about $(16.5 \%)$. While the fourth main reason of begging was illiteracy which shared about $9.7 \%$ beggars.

${ }^{35}$ UN-HABITAT (United Nations Human Settlement Programme) (2007): Enhancing urban safety and security: Global report on human settlements 2007. London, Sterling, VA. p:76, Available from: https://www.un.org/ruleoflaw/files/urbansafetyandsecurity.pdf[accessed Oct 2, 2008]

${ }^{36}$ Balachova, T., Bonner, B. L., \& Levy, S. (2009). Street children in Russia: Steps to prevention. International Journal of Social Welfare, 18(1), 27-44. 
Table: 2

Contingency Tables and Testing of Hypotheses

Ho: Beggars are not eager to suggest their children to adopt the same profession in future Calculated Value of chi-square $x^{2}=0.070746$

\begin{tabular}{|c|c|c|c|}
\hline \multirow{3}{*}{$\begin{array}{c}\text { Satisfied With Their Profession } \\
\text { YES } \\
\end{array}$} & \multicolumn{2}{|c|}{$\begin{array}{l}\text { Willing To Suggest Their } \\
\text { Children To Adopt The Same } \\
\text { Profession In the Future }\end{array}$} & \multirow{3}{*}{$\begin{array}{r}\text { Total } \\
\\
49\end{array}$} \\
\hline & YES & NO & \\
\hline & $\begin{array}{c}35 \\
(64.0 \%) \\
\end{array}$ & $\begin{array}{c}14 \\
36.1 \%\end{array}$ & \\
\hline NO & $\begin{array}{c}23 \\
(36.0)\end{array}$ & $\begin{array}{c}68 \\
(63.9)\end{array}$ & 91 \\
\hline TOTAL & 58 & 72 & $140(n)$ \\
\hline
\end{tabular}

Tabulated value of chi-square $=3.841$

Table: 3

Ho: there is a significant relationship between Substance abuse and beggar's involvement in criminal activities

\begin{tabular}{|c|c|c|c|}
\hline \multirow{2}{*}{ Substance abuse } & \multicolumn{2}{|c|}{ History of crime } & \multirow{2}{*}{ Total } \\
\cline { 2 - 3 } & Yes & No & \\
\hline Yes & $58(84.0)$ & $14(19.4)$ & 72 \\
\hline No & $11(16.0)$ & $57(79.1)$ & 68 \\
\hline Total & $\mathbf{6 9}(100)$ & $\mathbf{7 1 ( 1 0 0 )}$ & $\mathbf{1 4 0}(\mathbf{1 0 0})$ \\
\hline
\end{tabular}

$\mathrm{DF}=1$

Level of Confidence: $1 / 100=0.01$

CalculatedValueofchi - square $=x^{2}=23.043$

Tabulated Value of Chi-square $=3.84$

The findings of this study indicated that there is a significant relationship between drug abuse and involvement in crimes with begging with $\mathrm{p}$ values $<0.05$.This data showed that smoking and abusing drugs and high prevalence rate of delinquency are the important contributors to beggary,this result confirmed the research of ThakkerY,et $\mathrm{al}^{37}(2007)$ that many beggars were exposed to stressful conditions that lead to anxiety disorders and depression.

${ }^{37}$ Thakker, Y. Gandhi, Z., Sheth, H., Vankar, G. K. \& Shroff, S. Psychiatry Morbidity Among Inmates of the Beggar Home. International Journal of Psychosocial Rehabilitation, (2007), 11(2), pp.31-36 
Table: 4

Ho:There is a significant relationship between socio-financial reasons and beggar's involvement in criminal activities

\begin{tabular}{|c|c|c|c|c|c|}
\hline & \multicolumn{4}{|c|}{ Beggars participation in criminal activities } & \\
\hline $\begin{array}{l}\text { Reason for } \\
\text { starting Begging } \\
\text { criminal } \\
\text { activities. }\end{array}$ & $\begin{array}{l}\text { Personal } \\
\text { choice to } \\
\text { join inn } \\
\text { anti- } \\
\text { social } \\
\text { activities }\end{array}$ & $\begin{array}{l}\text { Criminal } \\
\text { family } \\
\text { members } \\
\text { or } \\
\text { relatives }\end{array}$ & $\begin{array}{l}\text { Pressure/Support } \\
\text { of Political } \\
\text { Parties }\end{array}$ & $\begin{array}{l}\text { Friends } \\
\text { Pressure }\end{array}$ & Total \\
\hline Financial & $\begin{array}{c}5 \\
15.6 \%\end{array}$ & $\begin{array}{c}5 \\
14.3 \%\end{array}$ & $\begin{array}{c}5 \\
27.8 \%\end{array}$ & $\begin{array}{c}20 \\
30.8 \%\end{array}$ & $\begin{array}{c}35 \\
23.3 \%\end{array}$ \\
\hline Social & $\begin{array}{c}19 \\
59.2 \%\end{array}$ & $\begin{array}{c}18 \\
51.4 \%\end{array}$ & $\begin{array}{c}7 \\
38.9 \%\end{array}$ & $\begin{array}{c}31 \\
47.7 \%\end{array}$ & $\begin{array}{c}75 \\
50.0 \%\end{array}$ \\
\hline Both & $\begin{array}{c}8 \\
25\end{array}$ & $\begin{array}{c}12 \\
34.4\end{array}$ & $\begin{array}{c}6 \\
33.3 \%\end{array}$ & $\begin{array}{c}4 \\
21.5 \%\end{array}$ & $\begin{array}{c}30 \\
26.7 \%\end{array}$ \\
\hline Total & $\begin{array}{c}32 \\
100.0 \%\end{array}$ & $\begin{array}{c}35 \\
100.0 \% \\
\end{array}$ & $\begin{array}{c}18 \\
100.0 \%\end{array}$ & $\begin{array}{c}55 \\
100.0 \% \\
\end{array}$ & $\begin{array}{c}40 \\
100.0 \% \\
\end{array}$ \\
\hline
\end{tabular}

$\mathrm{DF}=6$

Level of Confidence: $1 / 100=0.01$

Calculated Value of chi - square $=x^{2}=23.043$

Tabulated Value of Chi-square $=3.84$

On the basis of the above data, it is anticipated that peer pressure is an important factor among beggar's involvement in criminal activities and criminal beggars socially enjoy the status of beggars and considered it as a support. This finding is supported by BioPsycho-Social model ${ }^{38}$ developed at Rochester University by Drs. George Engel and John Romano. This model suggests that biological, psychological and social factors play an important role.

During the process of data collection from the target population it was observed with great concerns that beggars have a strong underground culture and while conducting interviews 3 men and 2 women arrived in nice clothes asked the researcher about what you are doing and they influence the respondents during the data collected by the researcher. It was observed during data collection in many settings, the respondents deliberately avoided giving information about beggar's mafia.

To inquire about the existing situation, the researcher also took a short interview with a Senior Social Welfare officer(who does not want to disclose his name), deputed at the Social Welfare Office at Civic Center stated that it is observed that in most of the street

\footnotetext{
${ }^{38}$ Frankel RM, Quill TE, McDaniel SH, The Biopsychosocial Approach: Past, Present, Future.(Rochester, NY:
} University of Rochester Press, 2003), p.67 
crimes the beggars directly or indirectly involved. Ironically, some beggars involved their children, especially disabled children to beg on particular days and events like Thursday, during Ramadan, and during Public holidays as these days as highly regarded as " peak session " for them .

The researcher took another in-depth interview with a 16-year-old, soft-spoken, beautiful male, in his mid-teens, had a single parent, living at Gulistan-e-Johar, near the Saforra round-about, who told that:

\begin{abstract}
I belong to Abbottabad; I lost my father in my early childhood as he died in an earthquake. My mother got married to another man belongs to very poor socioeconomic status. I was neglected and I feel that my mother has no time for me. The death of my father puts me in such a situation in which I was unable to work and my underprivileged mother was unable to cater my basic needs due to her illiteracy. There was a lot of poverty and hunger I faced at that time. Under these circumstances, my father's dream to provide me a better life and formal schooling vanished. By that stage, I opted to be on the streets. I find some children who use to beg and I joined their company. Initially, it was an individual decision of mine and I start begging with a hope that this is the best way to utilize my time and earn money to fulfill my needs. I feel comfortable on the street than at home. I worked for almost a year and then I moved to Karachi with a few friends of the same profession. Here, I faced many challenges for re-settlement in the profession, but interestingly, I did not face any barrier of language or caste to adjust with local beggars. I worked here as a professional beggar and spent half of my money on alcohol. I have no contact with my mother or other relatives. Finally, I linked with a begging group and I live with them safely and comfortably. This group work for dakkos (those who involve in theft and robbery) and provide them assistance as an informer. I did not want to work any other job and would take the job continued. Last summer, the police picked up me along with other two fellow beggars - suspecting us to be criminals, but the matter was resolved out of the police station". $\mathrm{He}$ disclosed very boldly.
\end{abstract}

Whatever the truth, it is clear that in Karachi, thousands of beggars are present on the streets. They are generally observed by the community police. The above-noted interview is the reflection of UNICEF's ${ }^{39}$ definition (2006), "children on the street have family ties" More importantly, it was observed during data collection that most of the regular beggars were alleged or perceived criminals, targeted by police in many criminal cases like snatching mobile phone, picking cash and run away, robbery, neither they recognized as criminal nor have any legal or criminal record on papers. It is noticed that most of the cases a relaxation has been given to them because of their poverty.

Another individual, working as a Social Worker in an NGO situated in Gulshan-e-Iqbal shared his views that:

I have been working in an NGO since 2011 and debuted here in the Gulshan branch of the office. I have observed a woman used a typical begging tactic.

39 United Nations Children's Fund.(UNICEF). Children first: Children living and working on the streets, (2006). Available from:http://www.unicef.org/turkey/dn_2006/_cp43.html[accessed Oct 2, 2008] 
She is continuously visited in our office, whenever she came, she asked for financial support, appealing to give her donation as she has received a medical recommendation from and according to it she is unable to perform heavy duties. She moves with the medical document supporting her claim and asking for help.

The above-mentioned statement of a social worker reflects the current trends of begging in society. In the absences of a vigilant monitoring system of the government, beggars have engaged in such practices to catch the human sympathy and also involved in antisocial activities in the city.

\section{Conclusions}

Conventional wisdom advocates that beggars are not instinctive or born, but shaped by the society where they live and grow. This study noticed that homelessness, poverty, unemployment and family rejection are the connecting factors which are directly linked with begging. There is a strong social network regarded as a key component in the life of street beggars which provide a lot of support, protection and facilitate them in their personal, social, economic life as viewed by the present study. The researchers observed serious lapses in maintenance of effective check and balance systems on the streets. This situation helps and facilitates the criminal beggars in performing their task. It can be concluded that the socio-economic status of street beggars, especially in urban areas and their involvement in an anti-social activity, distresses the Pakistani culture. Therefore, it should be considered as a national problem and necessary policies must be designed to reduce this social problem otherwise, this manifestation becomes a constant security hazard in many shapes for common people and the Government as well.

\section{Recommendations}

On the basis of above-mentioned analysis, this research suggests that:

It is revealed that the absence of legal earning opportunities and weak police monitoring system are listed as exclusive factors for beggars' involvement in criminal activities in Karachi. This research endorses that for controlling street begging and its contributing factors, policy makers and public authorities may implement multi-dimensional interventions on the basis of socio-religious and psycho-economic factors.

This study strongly recommends that the government should take necessary vigilant, preventative and responsive steps for the elimination of all types of begging especially criminal beggars and powerful mafia groups from society.

There is a strong need to set or design the "eligibility criteria" for donation or charity through appropriate urban charity policy. There is a need to design a proper system for the welfare of genuinely deserving people in every community (Muhalla) or union council or town level. Furthermore, through proper monitoring and collecting weekly charity or donation from the community through Social Workers, support the needy people at their doorstep in the same community decently. 
Restoration of beggars' social assistance and proper record of genuine or deserving people is also needed at the community level in the city.

Comprehensive policies are required to address this issue within proper legislative contexts. In this connection, Beggars would not be permitted to work in the streets. Furthermore, necessary measures should be taken to ban on beggars for migrating from one city to another city. Media campaigns can play a vital role in discouraging the begging practices. 